\title{
O DIREITO COMO INSTRUMENTO DE REALIZAÇÃO DA JUSTIÇA E A MISSÃO CONSTITUCIONAL DO JUIZ NA ELABORAÇÃO DAS DECISÕES JUDICIAIS
}

\author{
Custodio da Piedade U. Miranda \\ Professor Associado do Departamento de Direito Civil da \\ Faculdade de Direito da Universidade de São Paulo. Advogado \\ em São Paulo.
}

Resumo:

O artigo sustenta que o que se pode, nas decisões judiciais, na atual ordem constitucional em que vivemos, é procurar alcançar o justo posto por convenção, nas normas legais e não o justo natural, segundo o sentimento individual e o sentido subjetivo de Justiça do juiz ainda que em contrário do que dispõem as normas legais. Mais: enfoca o Direito, predisposto nas normas que constituem o ordenamento, como o instrumento necessário da realização da Justiça, entendida esta como a atribuição do bem, objeto de disputa num pleito judicial, a um dos sujeitos dessa disputa, de acordo com a decisão a que o juiz chegar mediante o cumprimento e a aplicação regular ao caso de todas as normas legais imperativas, sejam de Direito Público, sejam de Direito Privado, de direito material ou processual, atendidas as circunstâncias concretas. É essa a missão que lhe foi imposta na Constituição. Não basta, porém, a mera observância das normas legais na decisão judicial. Ela há de resultar da aplicação dos princípios gerais postos a descoberto pela Ciência do Direito.

\begin{abstract}
:
The article upholds that one may, in judicial decisions, under the current constitutional order, attempt to reach fairness brought by convention in legal rules and not natural fairness, according to individual feeling and the Judge's subjective feeling of Justice even though contrary to the provisions of legal rules. Further: it focuses law, set forth in the rules which make up the legal system, as the instrument necessary to do justice, which is construed as the attribution of a good, which is the object of dispute in a judicial controversy, to one of the subjects of such dispute, according to the decision which the Judge reaches through compliance with and the regular enforcement to the case of all imperative legal
\end{abstract}


rules, whether of public or private law, or of material or procedural law, with due regard to the concrete circumstances. That is the mission which has been imposed upon him by the Constitution. It is not enough, however, to merely comply with the legal rules in the judicial decision. The decision must result from the enforcement of general principles laid open by the science of law.

Unitermos: Direito; Justiça e elaboração de decisões judiciais.

I

Muito se tem debatido ao longo dos tempos sobre os conceitos de Direito e de Justiça pelo que pode parecer pretensioso o título deste artigo, como que a sugerir um discurso original sobre tão antigos quanto renovados temas. Mas o propósito é outro. O que se quer é tecer algumas reflexões em torno do Direito e da Justiça, enquanto elementos, não propriamente de utensilagem conceitual, mas de instrumentos de disciplina da vida em sociedade. O que nos leva a analisar, por um lado, o Direito, como instrumento da realização da Justiça e o conceito de Justiça, enquanto objetivo das decisões judiciais, que será o justo por convenção e não o justo por natureza e, pelo outro, o modo conseqüente como elas devem orientar-se, pela observância obrigatória de normas imperativas e dos princípios gerais, postos a descoberto pela Ciência do Direito, tudo ao serviço daquele fim último, que é a ordenação e distribuição dos bens da vida, sempre limitados, em função da satisfação dos ilimitados interesses humanos.

As considerações que se seguem não representam evidentemente uma tomada de posição definitiva sobre as questões que aqui se abordam, mas uma espécie de pausa, no percurso de uma longa caminhada' ' de quem tendo de lidar no dia a dia com os mais variados tipos de controvérsias que são debatidas no foro, em todas as instâncias, sente a necessidade de olhar as coisas de um modo crítico, no melhor sentido da palavra, sem qualquer arrogância ou submissão, mas com toda a objetividade possivel, começando por indagar-se, de modo introdutório, do alcance de expressões muito em voga, nos dias atuais, tais como crise do Direito, crise da Justiça, crise do Judiciário.

1.0 autor já cxerceu as funções de promotor de Justiça, juiz de Dircito e de advogado que ainda excrcc, no Brasil, cm São Paulo, nos sistemas da civil law c da common law c cm três paiscs, com legislaçõcs obviamente diferentes. 
E, sem dúvida, há uma grande parcela de verdade em tudo isso.

Há uma crise no Direito: a) pelo descompasso cada vez maior e mais rápido entre o Direito e a Vida, pois a variedade, multiformidade e novidade dos fatos desafia qualquer atividade legislativa, tanto mais precária e insuficiente quanto é certo que não se descobriu ainda, na elaboração das normas jurídicas, nenhum outro método que não seja pelo recurso à formulação da hipótese de fato e da respectiva estatuição; b) pelo próprio formalismo da atividade legislativa, com o seu sistema bicameral, de gestação lenta, que torna praticamente impossível a regulação imediata das questões da vida, carecedoras de tratamento e que explicam entre nós, as medidas provisórias e a sua permanente reedição, contrariando a letra e o espírito da Constituição; c) pelo sistema da elaboração das leis que, não-obstante passarem pelo crivo das Comissões, encarregadas de depurarem-nas de vícios formais e substanciais, ${ }^{2}$ deixam muito a desejar no aspecto da isenção desses vícios, até porque tais Comissões, na sua constituição, atendem mais aos interesses político-partidários do que propriamente aos da boa técnica legislativa, como deveria ser.

Há uma crise na Justiça: a) da justiça social, com a péssima distribuição de renda, e o conseqüente baixo poder aquisitivo da maioria da população, em função de um aviltante salário minimo, de um desemprego inquietante, devido, entre outros fatores, aos males da globalização e da própria consciência cívica das camadas mais altas da população; b) da justiça laboral, com a grande concentração da riqueza produzida com o fruto do trabalho humano nas mãos dos detentores do capital, a grave questão social de sempre, nunca superada e pouco resolvida, não obstante o sangue, suor e lágrimas de tantos que por ela lutaram no tempo e no espaço e que não mereceu mais do que tímidas intervenções legislativas, pelo menos em países como o Brasil; c) da justiça previdenciária, com os permanentes rombos nos fundos públicos da previdência social, não obstante as suas fabulosas arrecadações, mais devidos à insensatez, à falta de escrúpulos e de um mínimo de senso de honestidade dos que têm acesso aos seus cofres ou aos que lidam com o dinheiro público, com o conseqüente flagelo para a população de trabalhadores que consumiram as suas energias e renunciaram ao lazer, numa vida inteira de infatigável labuta, para, ao fim, nos anos que ainda lhes restam, não terem sequer direito a uma justa remuneração do capital, empatado com as contribuições; etc.

2.Tais como a violação da Constituição, a má, por vczcs, pćssima formulação das normas, qucr na sua rcdação, quer na sua intclccção, scm prcocupação, por outro lado, de qualquer cocrência sistcmática. Volta-sc a dizer aqui que toda a regra tcm as suas cxcç̧õcs. 
Há uma crise no Judiciário, não-só limitada aos desmandos dos que detêm as rédeas da administração dos seus recursos, que nos parece não se tratar de uma questão generalizada, mas que tem sido a tônica da CPI respectiva, o que só por si revela de antemão o fraco sucesso que terá na solução da crise desse Poder, crise essa que se estende também à quase falência da administração da Justiça em razão do acúmulo dos processos e da inevitável e anormal demora nas decisões judiciais, mas que envolve também outros gravíssimos males, estes sim, que se constituem, em nosso entender, no cerne da crise, tais como a liberalização da idade mínima para os candidatos a concurso, já formados em faculdades deficientes, a não-exigência de qualquer experiência prévia, digna desse nome, desses candidatos, adquirida no exercício efetivo e frutuoso da advocacia, a elaboração de decisões por assessores de magistrados, sem a necessária qualificação à altura das tarefas que se lhes exigem, tudo com reflexos muito sérios no nível dessas decisões, na maioria das vezes mal redigidas, mal fundamentadas, quando o são, do ponto de vista legal e científico e quando o são parcialmente, tornam-se irremediáveis já que o remédio legal, dos embargos de declaração, é, em regra, totalmente infrutífero, porque é o próprio magistrado visado - juiz na $1^{\text {a }}$ instância ou o relator do processo, na $2^{\text {i }}$ - que julga, neste último caso, passivamente acompanhado, na decisão, pelos seus pares (passividade que, aliás, já se tornou regra na apreciação dos recursos em geral, o que converte o colegiado recursal num juiz singular, contrariando a própria razão de ser do recurso), sem nenhuma preocupação pela oportunidade que lhes dão os embargos, de aprimorarem a prestação jurisdicional, parecendo que se vê neles uma afronta à sua sabedoria e infalibilidade. ${ }^{3}$

É no contexto dessa crise, referida em último lugar, que têm valimento as considerações que se passam a desenvolver.

II

Quando falamos em Direito não nos referimos, para efeitos desta análise, à jurisprudência, embora seja esta uma autêntica fonte de Direito, mas principalmente ao

3.Tudo o que se cstá dizendo ć fruto da cxpcriência profissional do autor c sc faz com todo o respcito, $\mathrm{scm}$ a minima intenção de ofender ou agredir quem ou o que quer que scja, apcnas no intuito de constatar a dura realidade que se cnfrenta no Judiciário. Está-sc falando aqui, por outro lado, da regra que, por definição comporta excç̧ões, cmbora tão honrosas quanto cscassas. À crisc derivada do acúmulo dos processos tcm-se pretendido obviar com cxpedientes que podem ser de grande valia, como por cxemplo, a introdução da súmula vinculante, quc achamos válida, $\mathrm{cm}$ princípio, cmbora com ccrtas restriçõcs, mas que não cnfrenta as questões mais profundas dessa crisc, referidas no texto, $\mathrm{c}$ às quais tem sido totalmente alheia a nossa Ordem dos Advogados. 
Direito posto, isto é, às leis e demais atos normativos, vigentes no País e à doutrina, mais precisamente à Ciência do Direito, utilizada, na forma de princípios gerais, como instrumento indispensável de solução de questões jurídicas, resolvidas em decisões judiciais.

A preocupação aqui é a de sinalizar tudo o que possa contribuir para enfrentar a dispersão caótica das leis e das decisões judiciais, de modo a reconduzi-las a um sentido de unidade que possa garantir a certeza do Direito nas relações jurídicas, numa sociedade multiracial, culturalmente compósita e com grandes desníveis de riqueza e de educação, o que nos leva a repensar alguns conceitos, tais como os da Justiça, da missão constitucional do juiz, da necessidade de se alcançar a uniformização da jurisprudência, etc.

Cada vez mais, põe-se em causa o método tradicional da solução das questões submetidas à apreciação do Judiciário, que se fundava em critérios de pura lógica formal e do raciocínio dedutivo-silogístico, fruto da teoria subsuntiva, que via na sentença judicial a resolução de um silogismo em que a premissa maior era a lei, a menor, os fatos e a conclusão, a dedução que se seguia da aplicação da lei aos fatos: dura lex, sed lex. A solução se obtinha pela operação da subsunção dos fatos concretos à hipótese fática prevista na lei para, a partir daí, aplicar-se a norma que disciplinava tais fatos.

Cedo se viu que as coisas não são tão simples assim; o juiz não pode ser um mecânico operador de subsunções para encontrar no quadro normativo uma solução pronta e acabada para o caso concreto; já não se fala no caso omisso, não previsto nas normas legais para o efeito de a lei dar-lhe um tratamento, que para isso o próprio ordenamento preveria a solução: analogia, costume e princípios gerais de Direito (art. $4^{\circ}$ da Lei de Introdução ao Código Civil). O juiz - diz-se - não se limita a aplicar a lei, ele realiza o Direito, há todo um processo criativo inerente à elaboração da sentença, corrigindo as distorções que resultam da aplicação fria dos textos legais ao caso concreto, numa situação em que se debatem, palpitantes, interesses humanos, em que a maior parte das vezes se jogam e se comprometem, em toda a medida, sentimentos, afetos, emoções... Donde ter de se substituir a lógica formal pela lógica emocional na decisão judicial.

Também aqui há uma grande parcela de verdade em tudo isso e, nãoobstante o problema ser muito mais complexo, só podendo, no entanto, versar-se agora numa pequena dimensão, compatível com o âmbito deste trabalho, é mister dizer-se alguma coisa sobre o modo como essas posições extremas (subsunção ou total 
liberdade na apreciação do caso concreto) devem situar-se na atividade judicante, ou seja, em que limites, cada uma delas, deve contribuir para o pronunciamento das decisões judiciais.

A operação de subsunção é indispensável na elaboração da sentença, não propriamente para se chegar a uma decisão no caso concreto, com o recurso à dedução silogística da lógica formal, como o queria a teoria subsuntiva, mas para a identificação da lei (da norma ou das normas) aplicável ao caso, mais precisamente para se saber em que normas legais estão previstas as hipóteses de fato a que, com maior ou menor aproximação, se ajustam os fatos concretos, objeto da controvérsia, que terá de ser decidida à luz dessas mesmas normas. A subsunção é necessária, indispensável mesmo, para a determinação do material normativo com que o julgador terá de operar no caso concreto e termina ali a sua função.

A identificação das normas em que estão abstratamente previstas as situações do tipo das que são objeto de análise, para o efeito da solução da controvérsia, constitui-se numa atividade indispensável ao julgador, porque as normas, elaboradas pelos representantes do povo, do qual emana todo o Poder (parágrafo único do art. $1^{\circ}$ da Constituição Federal), é que contêm, em vista da própria estrutura que as torna aptas a serem o instrumento da disciplina da vida social, tal como de há muito é examinada pela Ciência do Direito, o esboço da solução a ser dada a toda a controvérsia em que duas ou mais partes disputam entre si um bem de vida e em relação ao qual se posicionam numa atitude de afirmação e negação.

Quer isso dizer que não é dado ao juiz criar ${ }^{4}$ a norma jurídica que irá reger o caso concreto, precisamente porque, dentre outras razões, a independência e a harmonia dos diversos Poderes da República (art. $2^{\circ}$ da Constituição) supõem que um não invada a esfera da atuação do outro, fato que certamente ocorreria se se atribuísse ao juiz o poder de criar normas.

Entender-se o contrário, implicaria em impor aos jurisdicionados,

4.Ainda que sc possa falar, numa atividade de criação, por dclegação do Icgislador, $\mathrm{cm}$ situações cxcepcionais $\mathrm{c} \mathrm{cm}$ limites preestabelccidos, por cxcmplo, na detcrminação do sentido c alcance de cláusulas gerais ou conceitos indetcrminados, na fixação de um máximo c de um minimo de penalidade, na adaptação da norma cxtraida de um caso previsto para um caso análogo ou a ser extraída dos princípios gcrais de direito, c, cnfim, na própria solução da controvćrsia pcla aplicação das normas ao caso concreto, pela necessidade de particularizar a norma ao caso, ao invćs de resolver o caso pela aplicação da norma. Sc

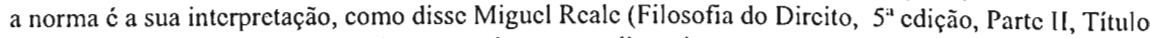
$X$, Capítulo XXXVIII), o juiz, cada vez que interpreta, dir-se-ia, cm certo sentido, que recria a norma na sua aplicação ao caso concreto, ctc. 
cidadãos que desfrutam de direitos e garantias individuais, inerentes à ordem democrática instituída pelo Poder Constituinte do qual emanou a Constituição da República promulgada em 5 de outubro de 1988, e nesta previstos, algo que começa por violar o próprio Preâmbulo da Constituição, porque o exercício desses direitos sociais e individuais só pode ficar assegurado se não houver essa arbitrária invasão das respectivas esferas de atuação, atribuindo-se ao Poder Legislativo o de elaborar as leis e ao Judiciário o de aplicá-las da melhor maneira possível na resolução de controvérsias submetidas à sua apreciação.

Não se está com isto a dizer que é esse o melhor sistema, mas é o que se constitui nos fundamentos básicos da ordem em que vivemos, não se tendo descoberto ou posto em prática, até hoje, já neste terceiro milênio, outro que, melhor do que a democracia representativa, assegure a Paz e a Justiça social. Se não-obstante esse sistema, a que é inerente - repita-se - o princípio da independência e a harmonia dos Poderes, os objetivos a que ele se propõe não foram alcançados é outro problema, cuja discussão, que se situa no campo da filosofia da política, escapa ao âmbito do nosso tema.

Dadas essas premissas é que há que discorrer sobre o cerne do nosso tema que não podia prescindir das considerações preliminares até aqui feitas.

III

Ainda que o ponto de partida das nossas reflexões seja considerar-se limitado o mister do juiz a julgar as controvérsias que lhe são submetidas à apreciação, em face do que dispõem as normas jurídicas, trazidas à colação mediante operações de subsunção, não se pode ver aqui o termo de sua atividade na apreciação do caso concreto, nos moldes do que proclamava a teoria subsuntiva, mas o seu início, o começo de um laborioso percurso pelo ordenamento jurídico, encarado como um sistema, na busca da melhor solução para o caso à luz desse sistema.

Todo o texto jurídico, como se sabe, para ser aplicado, há de ser interpretado e a interpretação é que vai revelar de que modo ele se articula no sistema, começando por ter de se examinar qual o sentido que comporta no contexto da Constituição (interpretação conforme à Constituição), no conjunto de todos os atos normativos que integram o ordenamento e no próprio ato normativo de que se trata (interpretação sistemática). É que, há que investigar em última hipótese o sentido lógico do texto, para além do seu sentido literal, o qual, aliás, terá de ser o seu ponto de partida. 
Goffredo Telles Júnior é quem o diz, magistralmente:

"Queremos aqui ressaltar uma conclusão importante. Se a aplicação da letra da lei a um caso concreto puder produzir efeito contrário ao que a própria lei pretende, aplicá-la equivale a violá-la, porque seria contrariar o seu pensamento, o seu espirito.

O juiz que a tenha aplicado assim, não soube interpretá-la; apegou-se à letra rígida da lei, desconhecendo o seu espírito. Ao juiz não é permitido julgar violando a lei; não é permitido julgar "contra legem" O que lhe compete é julgar em conformidade com o que manda a lei corretamente interpretada"

E mais adiante:

"Na interpretação das leis, mais importante do que o rigor da lógica racional é o entendimento razoável dos preceitos, porque o que se espera inferir das leis não é, necessariamente, a melhor conclusão lógica, mas uma justa e humana solução. O que se espera é uma solução atenta às variegadas condições de cada caso concreto a que a lei interpretada se refere" 5

Muito se tem insistido ultimamente em que os fatos, cada fato ou conjunto dos fatos do real, adquirem colorações diversas em função das circunstâncias concretas do caso, não podendo considerar-se sua similaridade como algo de imutável só porque a hipótese de fato que constitui a previsão da norma é a mesma. Isto implicaria em que o juiz, na sua atividade de busca de uma solução para o caso, teria de enveredar por um penoso percurso que passa dos fatos à norma, volta aos fatos, passa destes outra vez à norma, quantas vezes necessário, por não se sentir satisfeito ou seguro com a solução provisória que encontrou, até chegar à decisão final. Neste processo, dir-se-ia que os fatos é que são decisivos na realização da Justiça, a solução é o juiz que a encontra de acordo com os fatos, tendo a norma um sentido de orientação, embora obrigatória, na busca dessa solução. Seria como que a bússola a nortear o caminho a ser seguido para se encontrar uma adequada solução para o caso.

Todavia, esse pensamento só pode partir de uma premissa que para nós é inaceitável: a de que não há quaisquer limites para a atuação do juiz, na realização da justiça do caso concreto, o que supõe que ela pode variar, caso por caso, infinitamente, diga-se com algum exagero, necessário para melhor ilustração das coisas, de acordo 
com os valores do momento ${ }^{6}$ próprios da comunidade de que se trata e do sentido subjetivo de justiça do juiz que tem a sua própria concepção do mundo e da vida, na qual desde logo se incluem as suas convicções políticas, morais e, por vezes, religiosas, do que pode resultar, e com freqüência resulta, uma decisão de gosto individual, sem base objetiva e com total descaso da certeza e segurança jurídicas. ${ }^{7}$

E não é só. A própria expressão justiça do caso concreto já nos causa um certo arrepio. O que se quer dizer com esta expressão? As partes recorrem ao Judiciário para solucionar uma controvérsia, a disputa de um bem de vida e não compete ao juiz declarar do nada se é justo ou não que esse bem de vida fique com $\mathrm{A}$ ou com $\mathrm{B}$, e em que condições. Isso é algo que já está resolvido em tese pelo legislador; as normas jurídicas é que dispõem sobre a distribuição desses bens, estabelecendo-lhes não-só a pertinência e as condições em que serão atribuídos aos respectivos titulares, mas também as vicissitudes dessa relação de pertinência, desde a sua constituição até o seu término.

Ao juiz não compete mais do que declarar, em caso de controvérsia, o destino do bem no âmbito da relação jurídica de que se trata, tornando concreta uma solução já abstratamente esboçada nas normas legais, atendendo a todas as particularidades do caso. A Justiça que ele realiza consiste precisamente em dizer de que modo a comunidade entende que é justo que o bem fique com A ou com B; ela já fez as suas opções, através dos seus representantes que as externaram nas leis que

6.0 termo valor foi usado no texto, não no scu sentido verdadciro $\mathrm{c}$ próprio, mas num sentido peculiar. Valor naquele primciro sentido ć um bcm, moral ou cspiritual, não importa, mas $\mathrm{cm}$ si mesmo valioso, digno de ser buscado c alcançado, algo que intercssa a todos c insusceptivel de ser afastado ou ignorado c corre linhas paralclas com o sentimento universal de Justiça. Assim, a vida, a saúde c a segurança, a liberdade, a dignidade da pessoa, a honra, ctc. Valores no scgundo sentido são os que têm a ver com interesses humanos imediatos, que variam com o tempo $c$ que agradam a uns $c$ podem não agradar a outros, dependendo também da comunidade de que se trata. Tem a ver com um peculiar sentimento de Justiça, próprio de uma pessoa ou de um certo círculo de pessoas. Assim, uma modalidade desportiva, o lazer de uma pessoa scm grandes recursos, ctc. Um "valor" desta natureza foi o decisivo para um juiz, adepto do chamado Dircito Alternativo, numa ação $\mathrm{cm}$ que contendiam o vendedor de um televisor $\mathrm{co}$ consumidor, aquele plcitcando a reintegração de posse no aparcllı, por falta do pagamento das prestações do preço c cstc opondo-sc à rcintcgração com a alcgação de que cle havia sido comprado para o seu novo dono desfrutar dos jogos do futcbol da copa do mundo c que não cra justo que cle fossc privado do tclcvisor $\mathrm{scm}$ ver csscs jogos atć o fim do tomcio só porque cle cstava cm atraso no pagamento das prestaçōcs. O juiz sentenciou com csta frasc magistral: "Reintegrc-se, mas após a copa do mundo".

7.Certcza c segurança, dizem os adeptos dessa corrente, como falar-sc nisso num mundo de incertczas, do desconhecido, de permancntc adaptação a situações novas $\mathrm{c} \mathrm{cm}$ que ć indispensável que o homem saiba c possa conviver com todas estas coisas? "É idiotice pensar $\mathrm{cm}$ segurança"- declara um juiz do Rio Grande do Sul. "A segurança não cxiste" (Goffredo Telles Júnior, O chamado Dircito Altcrnativo, Revista da Faculdade de Dircito, v. 94, p. 73). 
regem a vida da mesma comunidade. É esse mesmo sentimento de Justiça da comunidade, que não autoriza que fatos do mesmo tipo, ocorridos embora em momentos distintos, tenham soluções substancialmente diferentes. A justiça do caso concreto tem de estar assim em harmonia com a justiça dos casos concretos, de todos os casos do mesmo tipo. Se não for assim, qual o valor que teria o princípio de isonomia, de igualdade perante a lei (art. $5^{\circ}$, caput), que é uma garantia expressa na Constituição Federal?

Com a expressão justiça do caso concreto só pode ou deve querer significarse (e não mais do que isso) que o juiz, na declaração do direito, levará em consideração todas as circunstâncias concretas do caso, havendo que particularizar as normas para esse caso já que elas foram concebidas de modo geral e abstrato, hipoteticamente, sem qualquer consideração de circunstâncias. Não quer com essa expressão dizer-se que se deva abstrair do que de modo abstrato e geral disse o legislador acerca de tal justiça, porque esta é muito mais profunda, teve de atender a um pano de fundo muito mais abrangente, aos anseios, não de duas partes que disputam um bem de vida, mas de toda uma comunidade e no modo como ela encara que essa distribuição deva ser feita.

É por isso que repudiamos visceralmente o chamado Direito Alternativo, cujo retrato foi dado assim por um juiz : "Em princípio obedeço a lei. Só não a obedeço quando ela se revela injusta. A lei injusta não deve ser aplicada. O papel de um juiz é o de buscar o justo, no caso concreto, com a superação do legalismo" O juiz que só obedece a lei vira instrumento do legislador. Deixa de ser um Poder. Nesse caso não há necessidade de juízes. Para que juiz, se o juiz tem de se submeter, sempre e sempre, ao legislador? Nós queremos trazer o humano para dentro do processo. O processo tem de refletir a angústia das pessoas" 10

8.Trata-se de um juiz ao tempo da 2" vara civel da comarca de Porto Alcgre, de nome Amilton Bucno de Carvalho que, pelas suas declarações arrepiava o próprio jornalista-repórter, como se pode ver do scguinte trecho: O juiz gaúcho Amilton Bucno de Carvalho , 43 anos, titular da 2 vara cível do Foro de Porto Alcgre, tem um orgullıo que faria corar de vergonha a imensa maioria dos juizes brasilciros: o de julgar cventual, mas deliberadamente contra o que manda a lei. Pode parecer chocante mas o juiz Amilton diz que "joga a lei às favas, scm nenhum problema de consciência, todas as vezes que considera injusta a aplicação dcla, num caso concrcto".(Rcvista, cit. p. 74).

9.Supcração, ou scja violação do que dispõc o inciso II do art. 5" da Constituição Fcdcral: "Ningućm scrá obrigado a fazer ou dcixar de fazer alguma coisa scnão $\mathrm{cm}$ virtude de lci". Imaginem! Um juiz apregoando a necessidade de se violar a Constituiçào no pronunciamento de decisõcs judiciais. Um juiz que manda a lci "aos quintos dos infernos", como cle próprio declarou. (Revista, cit. p. 74). Como sc pode levar a sćrio um tal Dircito?

10.Revista, cit., pp. 74/ 75 . 


\section{A propósito do chamado Direito Alternativo, já tivemos a oportunidade} de escrever' ':

"Que dizer do chamado Direito Alternativo? Que é uma aberração e se trata de uma concepção que não pode de modo algum ser adotada. Não se nega o louvável intuito dos que a ele recorrem na preocupação de fazer a Justiça no caso concreto, mas se é bom o fim, não são bons os meios e certamente podem não ser bons (e geralmente não o serão) os resultados. E há vários argumentos que nos levam a rejeitar de pronto essa orientação."

O primeiro deles é, sem dúvida, o da certeza e segurança jurídicas. Já acima se viu como e porque constituem-se num valor a ser alcançado e tão caro ao Direito como a própria Justiça, havendo até quem dê prevalência àquele ${ }^{12}$. Com efeito, se cada juiz julgasse à sua maneira, interpretando a lei com o sentido que melhor satisfizesse o seu sentimento subjetivo de Justiça, não haveria segurança jurídica alguma, ।'ão se teria um Direito certo, não podendo cada um saber de antemão em que lei vive, com que bens de vida contar, de que modo traçar os seus planos de vida e do futuro. Não haveria a indispensável paz social, a ordem, que só se podem alcançar com um Direito curto, seguro, predeterminado. Seria o reino do arbítrio, de um Poder, do Judiciário.

Por outro lado, e ainda no domínio da certeza e da segurança jurídicas, o ji: $z$ deve interpretar a lei de modo a extrair dela uma solução, não apenas para o caso concreto, mas que seja razoável para todos os casos daquele tipo, pois só assim se garantirá o princípio da igualdade de todos perante a lei. Uma interpretação individual, válida apenas para aquele caso, situação a que certamente conduziria o Direito Alternativo, atentaria não apenas contra a certeza e a segurança jurídicas, mas também contra o princípio de isonomia, de igualdade de todos perante a lei, pelo que uma tal interpretação seria frontalmente inconstitucional e, como tal, inaceitável.

11. Apostila de aulas proferidas ao $1^{\circ}$ ano da Faculdade de Dircito da Universidade de São Paulo no ano de 1999 sobrc: "Interpretação da Lci. Objeto da Interpretação. Mćtodos de Interpretação. Espécics de Interpretação. O Dircito Altcrnativo c a Eqüidade".

12.V. Francisco Amaral, Dircito Civil, na sua cxcelentc obra, escreve cstc autor: "Valor fundamental ć a justiça (p. 14). E mais adiantc, tratando da scgurança: "A scgurança jurídica significa a paz, a ordcm c a cstabilidade c consiste na certeza da rcalização do dircito. Os sistemas jurídicos devem permitir que cada pessoa possa prever o resultado de scu comportamento, o que ressalta a importância do aspecto formal das normas juridicas, a sua forma de cxpressão. O Dircito tem, por isso, como um dos valores fundamentais para muitos o primciro na sua escala, a scgurança, que consiste, precisamente, na certeza da ordem jurídica c na confiança da sua rcalização, isto ć, no conhecimento dos dircitos e devcres estabclecidos c na certeza do scu excrcício c cumprimento". 
O segundo argumento é o que concerne à realização da própria Justiça. Administrar a Justiça é dar a cada um o que é seu, o suum cuique tribuere dos romanos. Ora, é só a lei que vai dizer o que é meu e o que é seu, só a lei, predispondo as regras sobre as titularidades dos bens, é que pode estabelecer e definir essas titularidades de modo a garantir, por outro lado, a ordem e a paz social. Mais: assegurando-se a igualdade de todos perante as leis é que se assegura a realização da Justiça. Ora ao Judiciário compete dizer, num dado caso concreto, dentre dois interesses conflitantes, de que são sujeitos duas pessoas que disputam um bem, qual deles deve prevalecer. $\mathrm{O}$ juiz declara o Direito no caso concreto, abstratamente predisposto nas normas jurídicas. A missão do juiz é fazer Justiça desse modo, declarando o Direito e não criando a norma que ele próprio julga adequada para o caso concreto, afastando a regra que um outro Poder - o Legislativo - criou, nos termos da Constituição.

Daqui se vê - e é este um terceiro argumento - que qualquer decisão nos termos do Direito Alternativo é também frontalmente inconstitucional porque viola, antes de mais, o princípio da separação de poderes, estabelecido no art. $2^{\circ}$ da Constituição Federal. $\mathrm{O}$ juiz que decide segundo a eqüidade ${ }^{13}$ cria a norma que julga adequada ao caso concreto, afastando a que porventura exista, para regular o caso a decidir. Viola também o princípio constitucional da legalidade, segundo o qual ninguém é obrigado a fazer ou deixar de fazer alguma coisa senão em virtude da lei (art. 5, II). Se o juiz pode decidir segundo a eqüidade e não segundo a legalidade, pode decidir contra aquele que tenha agido nos termos da lei, ou de acordo com ela. Basta que, segundo a sua conviç̧ão pessoal, a norma aplicável ao caso lhe pareça injusta ou inoportuna."

IV

De tudo o que fica exposto se conclui que a missão do juiz é a de declarar o Direito para o caso concreto, já que ele está só abstratamente previsto nas normas legais para uma generalidade de casos, sem qualquer particularização. A particularização da norma ao caso concreto pode demandar e geralmente requer uma atividade criadora, do juiz de modo a compatibilizar com o espírito da norma o caso com as suas circunstâncias concretas. Mas isto, de modo algum, permite que o juiz ignore, em nome da Justiça do caso concreto, o que dispõem leis imperativas, quer de direito

13. Salvo quando isto ć autorizado pela própria lci, cm casos detcrminados. Assim, por cxcmplo, na aplicação da pena da perda do dircito ao scguro, art. 1.456 do CC, na arbitragcm, art. $2^{\circ}$ da Lci n. 9.307/ 96 , na defesa do consumidor, art." $7^{\circ}, 51-\mathrm{V}$, na divisão de águas comuns, CA art.73, parágrafo único. 
material, quer de direito processual. E quanto a estas últimas também em função de uma suposta "inferioridade" dessas normas, em razão da cada vez mais decantada instrumentalidade do processo.

Esta colocação leva a perguntar de que modo o juiz há de realizar o justo do caso concreto, sabido que, na busca desse tipo do justo, ele tem, muitas vezes, que ignorar leis imperativas que chocam o seu sentimento subjetivo de Justiça, fundado provavelmente no justo natural. Mas o justo natural pode não coincidir com o justo convencional, aquilo que a comunidade, através de seus representantes, entende como justo. Será que, nestas condições, poderá o juiz rejeitar o justo convencional para ficar com o justo natural? ${ }^{14}$

Ouçamos o que tem a dizer o já citado e eminente professor Goffredo Telles Júnior que dispensa apresentação e que no artigo já referido, após as palavras com que o inicia ("Estávamos em outubro de 1990. Eu vinha lidando com a Justiça com os problemas do justo e do injusto - havia mais de meio século"), escreve literalmente: "Fascinante devo dizê-lo o sonho de colocar, por cima do justo por convenção, o soberano justo por natureza. Sinto-me irmanado com os juizes do Direito Alternativo enquanto permaneço na pura esfera do sonho"...15

Voltando à indagação feita, o juiz há de pretender alcançar o justo concreto a partir do justo convencional e não do justo natural, o que desde logo quer dizer que pouco importarão as suas convicções pessoais para esse efeito ${ }^{16}$, ainda que elas possam ser, e normalmente o são, importantes na medida em que permeiam a interpretação da

14.Um excmplo muito sugestivo poderá scr dado. O aborto ć uma violência c certamente contrário ao justo por naturcza. Suponhamos que uma mulher, ao abrigo das lcis do país, que permitem o aborto, $\mathrm{cm}$ ccrtas condiçõcs, pretende realizá-lo, num Hospital Público, cujo dirctor, por conviç̧ões próprias, recusasc a exccutá-lo. A mulher recorre ao Judiciário para fazer valer o scu dircito. Poderá o juiz, cm nome do justo natural, negar à mulher o dircito que plcitcia? Deccrto que não.

15.E prosseguc o mesmo cminente jurista: "Esse ć o sonho. Mas ć um sonho de todos nós. Todos nós temos un compromisso com a Justiça concretizada. Todos nós precisamos fazer Justiça concretizada, nos atos comuns da vida. E todos nós de fato buscamos praticá-la, $\mathrm{cm}$ nossas casas, $\mathrm{cm}$ nossos ambientes de trabalho, no clube, na rua". E mais incisivamente ainda: "Mas, no caso de conflito entre aparĉncias diferentes de Justiça concretizada, que fazemos? Vamos ao Juiz, para que cle diga quem tem razão, de acordo com as leis. O que pedimos ao juiz não ć, ccrtamente, que cle nos revele a sua doutrina c suas aspiraçõcs sobre o caso concreto. O que pedimos ć que o juiz nos diga o que a lei manda, no caso concreto. O que quercmos ć nos submeter à lci , não ao juiz, não às tcoria do juiz, à revclia da lci" (Rcvista da Faculdade de Dircito v. 94 p. 76, 1999).

16.Assim, c voltando ao excmplo dado anteriormente cm nota, pode o juiz, pessoalmente, scr contra o aborto, incondicionalmentc, mas sc as lcis do pais o permitcm, $\mathrm{cm}$ ccrtas condiçõcs, não tcrá como dcixar de aplicar a lei, quando a mulher o requer, nas condições $\mathrm{cm}$ que a mesma lei o permitc. 
lei e conseqüentemente a particularização dela ao caso concreto, mas sem que isso implique, seja em que medida for, na sua violação.

"O justo por convenção é aquilo que é tido como justo porque assim se convencionou...

"Esta é uma contigência de que os seres humanos, que vivem em sociedade, não se podem livrar. Sem uma convenção básica sobre o quê, de modo geral, deve ser tido como justo, impossível seria a convivência. Não há quem não entenda que ela é condição da convivência, condição da sociedade humana.

Essa convenção básica tem um nome: ela é o contrato de ética social" 17

A observância das leis imperativas, de todo e qualquer ramo de direito, público ou privado, em que se exprime o justo, pactuado nesse contrato de ética social é assim, por esse motivo, obrigatória na elaboração da sentença judicial e porque estamos num sistema de lei escrita (civil law), onde os conflitos de interesses são resolvidos em tese pelo legislador, como o afirma Philip Heck ${ }^{18}$, com maior razão do que num sistema do direito dos casos (case law) e da obrigatoriedade do precedente (como ocorre no sistema da common law), pode dizer-se que cada caso é um caso, diferente do outro. ${ }^{19}$ Fato que não dá ao juiz o direito de ignorar a lei, ou de distorcêla, a seu talante, no anseio de realizar o seu justo concreto. Há de procurar o justo abstrato, convencional, refletido nas leis, que melhor possa ser realizado no caso

17.Goffredo da Silva Tclles Júnior, obra citada, p. $361, \mathrm{~cm}$ que se lê ainda: "Notcmos que cssa convenção não ć uma fantasia do cspirito humano. Aquilo que ć ticlo como justo ć tido como justo por força de uma experiência de vida, após um processo de convivência e de relacionamento humano. Para muitas circunstâncias, a própria vida normal, a própria vida pacifica da socicdade acaba apontando para o que ć mais conveniente à ordem na colctividadc. Indica os comportamentos que, de modo geral, devem ser tidos como justos." E mais adiantc: "O que verificamos ć que cla (rcferindo-sc à etica social) nada tcm de universal, nem de imutável. Ela não ć universal, pois cada colctividade tcm a sua própria ćtica; c não ć imutável porque a ćtica de uma colctividade vai mudando, como bem sabemos, ao sabor de mil influências divcrsas. A ćtica social se exprime por meio de normas, que são indicações c sinais de normalidade vigcnte, para a neccssária informação das pessoas, cm sua atividadc diária."

18.Philip Heck, Interpretação da lci c jurisprudência dos intercsses, tradução de Josć Osório, São Paulo, Saraiva, 1947.

19.Não se ignora que, cada vez mais, há uma interpenctração dos dois sistemas de modo que no sistcma da civil law recorre-se aos precedentes na decisão das questões concretas, cnquanto no sistcma da common law se legisla de modo a uniformizar-sc a jurisprudência cxistentc. O que ć condenável ć quc, como tem vindo ocorrendo cntre nós, cada vez mais, não obstante o sistema ser da lci cscrita, os tribunais, por comodidade ou outras razõcs, alhciam-sc totalmente das particularidades do caso concreto, invocando um precedente do mesmo Tribunal ou do Tribunal Superior, que, por vezes, se distancia consideravelmente do caso $\mathrm{cm}$ tcla. 
concreto. Isto só se alcançará se se tiver em conta uma certa idéia de Justiça que nos parece conveniente referir aqui.

Cumprindo o que dispõem as leis, de direito material e de direito processual, o juiz chega a uma conclusão que, num conflito de interesses entre duas ou mais partes que disputam um bem, leva-o a dar prevalência ao interesse de uma/s e a sacrificar correspondentemente o interesse de outra/s. A realização da Justiça no caso concreto consiste precisamente nisso: na fiel observância e no regular cumprimento do que as leis, devidamente interpretadas, prescrevem e que levam a um ou outro resultado, independentemente de quaisquer considerações pessoais do juiz sobre como ele entende e vê a situação a ser resolvida, segundo o seu sentimento subjetivo de Justiça.

É nessa medida que se diz aqui que o Direito é o instrumento da realização da Justiça; ele acha-se predisposto na lei, no ordenamento e ao juiz não cabe mais do que declará-lo no caso concreto. É a lei que diz de que modo deve operar a distribuição dos bens e serem satisfeitos os interesses de cada um; ela é disposta de modo geral e abstrato, em tese, e é mister do juiz, diante de um conflito de interesses, dizer de que modo a lei entendeu dever fazê-la no caso concreto. Tarefa árdua, por vezes mais difícil do que a do próprio legislador, uma vez que a interpretação supõe um labor que em criatividade pode superar o da geração da lei.

\section{V}

Dir-se-á, em face das afirmações que aqui se fazem, que se trata de idéias superadas, pois ninguém ignora que hoje, mais do que nunca, em face dos progressos da técnica, as rápidas transformações da sociedade, que já no passado foram responsáveis pela assim designada revolta dos fatos contra os Códigos, exigem técnicas legislativas diferentes, mediante a elaboração de micro-sistemas ${ }^{20}$, só compativeis com a atribuição de poderes cada vez maiores aos juízes como por exemplo os de determinar o sentido das cláusulas gerais e dos conceitos jurídicos indeterminados, o que supõe uma evidente atividade complementar à do legislador.

Não se nega, mas também aqui há que insistir em que se trata de parâmetros e de limites prefixados pelo legislador e que o juiz acaba por ter sempre de caminhar por veredas de pensamento que, por mais largas e inovadoras, encontrem

20.Temos entre nós alguns delcs, como o Código de Defesa do Consumidor, o Estatuto da Criança c do adolescentc, o Estatuto da Mulher Casada, a Lci de Locações de Imóvcis Urbanos, ctc. 
uma substancial ressonância no que foi querido e pensado pelo legislador. Pode se manifestar inconformismo com esse estado de coisas e afirmar-se que as exigência do mundo moderno, com toda a complexidade dos seus problemas e os requintes da sua técnica, responsável pelas rápidas transformações sociais e a inerente defasagem entre o Direito e a Vida, não se compadecem com o velho sistema, em que se tolhe a desenvoltura do Juiz e não se lhe permite que excogite soluções não previstas no quadro normativo, e que podem ser muito mais ricas como resposta adequada às questões que se debatem num pleito judicial.

O que não se pode é, como freqüentemente se faz, subverter as coisas e, num estado democrático de Direito, em que vigora a independência e a harmonia dos Poderes, atribuir-se ao juiz o papel do legislador ou ao Executivo o papel do Judiciário ${ }^{2}$ Que se altere, em primeiro lugar, o sistema de autolimitação dos Poderes, acolhido na Constituição Federal, abolindo-se o sistema de legalidade, de igualdade perante a lei e tantos outros, que situam cada um deles na esfera própria de modo que não se admita a invasão de um pelo outro. É claro que ninguém faria isso porque seria a anarquia, o caos. É bom o sistema que temos, enquanto não for descoberto um outro, melhor. Mas, enquanto o tivermos, não sejamos hipócritas.

O que se faz necessário é que os tribunais decidam bem, proferindo despachos, sentenças e acórdãos que, não só sejam sustentáveis em face do que dispõem as normas do ordenamento, mas também tenham base científica, utilizem no percurso do pensamento intelectivo que os conduz à conclusão, os princípios gerais da Ciência do Direito. Só assim é que imprimirão às suas decisões a necessária credibilidade e no raciocínio que os leva a dar prevalência a um dos interesses conflitantes, em face do outro, mediante a aplicação das normas do ordenamento, chamadas à colação por uma operação de subsunção, acabam por convencer a parte que sucumbiu de que era essa a única solução possivel, a atribuição do bem, objeto de disputa, ao autor e não ao réu, ou vice-versa. É nisto que consistirá afinal a realização da Justiça. ${ }^{2} 2$

São Paulo, abril de 2001.

21.Basta lembrar os poderes que sc atribucm, cada vez maiores, a ccrtos órgãos administrativos - o Cadc, os Procons, o Dccon - de instruir c julgar, $\mathrm{cm}$ processos administrativos, infraçõcs divcrsas, com a aplicação a final de scvcrissimas penalidades, ainda que postcriormente sujcitos ao crivo do Judiciário. Tal subversão, aliás, é fcita scm rebuços pclos juizcs, adeptos do chamado Dircito Altcrnativo.

22.Nào ć isto que ocorre na maioria das vezcs. Para ilustraçào do que aqui sc afirma remetcmos o leitor para o nosso artigo "A Ccrtcza c a Scgurança como Valores Fundamentais na Declaração do Dircito c na rcalização da Justiça, c o modo de atingi-las" (Revista da Faculdade de Dircito 94/ 349 - 1999). 


\section{Bibliografia}

Amaral, Francisco, Direito Civil, Introdução, Rio de Janeiro, Renovar, 1998, $2^{a}$ edição.

Heck, Philip, tradução de José Osório, Interpretação da lei e jurisprudência dos interesses, São Paulo, Saraiva, 1947.

Larenz, Karl, Metodologia da Ciência do Direito, tradução de José de Sousa Brito e José António Veloso, Lisboa, Fundação Calouste Gulbenkian, 1978;

Reale, Miguel, O Direito Como Experiência, São Paulo, Saraiva, 1967.

Tepedino, Gustavo, Premissas Metodológicas para a Constitucionalização do Direito Civil, em Temas do Direito Civil, Rio de Janeiro, Renovar, 1991;

Sichès, Luis Recasens, Nueva Filosofia de la Interpretacion del Derecho, México, Porrúa, 1973.

Telles Júnior, Goffredo,

.O Dïreito Quântico, Ensaio sobre o Fundamento da Ordem Juridica, São Paulo, Max Limonad, s/d;

. Iniciação na Ciência do Direito, São Paulo, Saraiva, 2001.

. O chamado Direito Alternativo, Revista da Faculdade de Direito, fasc.94, p.74, 1999. 